\title{
Bioremediation of pulp and paper mill effluent using isolated Bacillus strain and its impact on the $\mathrm{pH}$ of effluent
}

\section{NUPUR JOSHI, R.K. JAIN AND A.K. DIXIT}

Article Chronicle :

Received:

30.10.2017;

Revised :

14.11.2017;

Accepted :

24.11.2017
ABSTRACT : This study focussed on the effect exerted by Bacillus strain on the $\mathrm{pH}$ of the pulp and paper mill effluent. The study aimed at bioremediation of paper mill effluent using Bacillus stratosphericus, the result of the experiment indicated that after 48 hours of treatment a reduction in colour $(47 \%), \mathrm{COD}(73 \%)$ and lignin $(33 \%)$ was observed suggesting its potential tool for treatment of wastewater. In addition, the $\mathrm{pH}$ of the effluent was varied from 4-9 at regular interval of 1 unit and was inoculated with bacterial strain and was kept at $35^{\circ} \mathrm{C}$ at $200 \mathrm{RPM}$ for 48 hours. The study indicated that Bacillus possessed inherent capacity to adjust $\mathrm{pH}$ favourable for its growth ranging from $\mathrm{pH}$ 7.4-8.7.

HOW TO CITE THIS ARTICLE : Joshi, Nupur, Jain, R.K. and Dixit, A.K. (2017). Bioremediation of pulp and paper mill effluent using isolated Bacillus strain and its impact on the $\mathrm{pH}$ of effluent. Asian J. Environ. Sci., 12(2): 104-106, DOI: 10.15740/HAS/AJES/12.2/104-106.

Key Words :

Bioremediation, Colour, Lignin, COD 